\title{
Chemically activated carbon production from agricultural waste of chickpea and its application for heavy metal adsorption: equilibrium, kinetic, and thermodynamic studies
}

\author{
Gamzenur Özsin ${ }^{1} \cdot$ Murat Kılıç$^{2} \cdot$ Esin Apaydın-Varol ${ }^{2}$ Ayşe Eren Pütün ${ }^{2}$
}

Received: 27 October 2017 / Accepted: 21 March 2019 / Published online: 27 March 2019

(C) The Author(s) 2019

\begin{abstract}
The purpose of this study was to produce activated carbons (ACs) from chickpea (Cicer arietinum) husks by chemical activation $\left(\mathrm{KOH}\right.$ and $\left.\mathrm{K}_{2} \mathrm{CO}_{3}\right)$ and to examine their feasibility in removing heavy metals from aqueous solutions. In the case of $\mathrm{KOH}$ impregnation with a ratio of $50 \mathrm{wt} \%$, the most developed porosity was achieved, with a BET surface area of $2082 \mathrm{~m}^{2} / \mathrm{g}$ and a total pore volume of $1.07 \mathrm{~cm}^{3} / \mathrm{g}$. By using the product, the maximum adsorption capacities were found to be 135.8, 59.6 , and $56.2 \mathrm{mg} / \mathrm{g}$ for $\mathrm{Pb}(\mathrm{II}), \mathrm{Cr}(\mathrm{VI})$, and $\mathrm{Cu}(\mathrm{II})$, respectively. The experimental data were analyzed by various adsorption isotherm and kinetic models. Thermodynamic parameters such as $\Delta G^{\circ}, \Delta H^{\circ}$, and $\Delta S^{\circ}$ were also calculated. The results obtained in this study shows that adsorption onto chickpea-husk-derived activated carbon was endothermic and spontaneous for the removal of heavy metals from aqueous solutions.
\end{abstract}

Keywords Chickpea husk $\cdot$ Activated carbon $\cdot$ Chemical activation $\cdot$ Heavy metal $\cdot$ Adsorption

\section{Introduction}

Heavy metal contamination is actually a global problem, since metal ions cannot be biologically degraded to less toxic products and persists in the environment (Vassileva et al. 2013; Abdulrazak et al. 2017). Besides, these ions are toxic and hazardous to human health, since they affect human life via bioconcentration, bioaccumulation, and biomagnification in the food chain. Therefore, the treatment of heavy-metal-contaminated wastewaters is of a great importance (Hussain et al. 2017a, b; Rio and Martin 2012; Kaur et al. 2013). Considering the high discharge amounts of metals from industries like electroplating, mining, metallurgy, paint, ceramic, threats to ecosystems have gained considerable importance (Shu et al. 2016; Ramesh et al. 2012; Malik et al. 2017).

Gamzenur Özsin

gozsin@anadolu.edu.tr

1 Department of Chemical Engineering, Bilecik Şeyh Edebali University, Bilecik, Turkey

2 Department of Chemical Engineering, Anadolu University, 26555 Eskişehir, Turkey
Several methods have been developed for heavy metal removal such as chemical precipitation, filtration, electrochemical treatment, membrane separation, solvent extraction, and ion exchange (Ahmady-Asbchin et al. 2009; AlGhamdi et al. 2013; Rana et al. 2004; Ramana et al. 2010). Unfortunately, high installation and operating costs, the formation of secondary sludge, and incomplete removal of metal ions restrict the practical applications of many of them (Agarwal and Singh 2017; Hussain et al. 2017a, b). On the other hand, the adsorption process has been found to be superior to other techniques in terms of cost, efficiency, the simplicity of design, and ease of operation. There have been a variety of sorbents used in adsorption of metal ions such as agro-based materials, clays, limestones, zeolites, fly ash, activated sludges, polymeric adsorbents, nanosized materials, and their various modified forms (Sdiri and Higashi 2013; Farnane et al. 2017; Bestawy et al. 2013; Hossain et al. 2014; Zhang and Zhu 2015; Omar 2015; Taamneh and Sharadqah 2016; Han et al. 2017). But activated carbon (AC) is still one of the well-known and widely used effective adsorbents at industrial scale due to its large surface area and high adsorption capacity. Hence, its requirement is expected to increase day by day due to the application of increasingly stringent environmental standards and legislation (Thitame and Shukla 2016; Reddy et al. 2014; Pakade et al. 2017). 
AC can be produced by chemical and physical activation processes. In many cases, chemical activation offers several advantages such as decreasing activation temperature and producing a well-developed porosity by the application of various activating agents. Among the extensively used agents, $\mathrm{KOH}$ and $\mathrm{K}_{2} \mathrm{CO}_{3}$ have increasingly been used as the activation reagent turning out high specific surface area of the prepared ACs (Deng et al. 2010). Also, it is known that using $\mathrm{KOH}$ and $\mathrm{K}_{2} \mathrm{CO}_{3}$ results in a high yield and welldeveloped internal porosity (Abdel-Ghani et al. 2016; Li et al. 2017; Andas and Satar 2018).

Commercially available AC is considered expensive for many small-scale industries, and usage of AC may imply regeneration and reactivation procedures. Therefore, interests are focused on to produce AC from abundant, low-cost precursors such as lignocellulosic biomass. For instance, agricultural residues obtained from crops can be considered as promising precursors that can be used in this way. In this study, chickpea husks, an agricultural residue, were used in AC production, since chickpea production has reached large quantities in Turkey. FAO reported Turkey as one of the top producers of chickpeas throughout the world with an annual production rate of 450,000 MT in 2014 (Food and Agriculture Organization of the United Nations, Web site 2016) As a result, considerable amounts of husks are discarded as agricultural waste from the milling of chickpeas, and these by-products have lacked a value-added evaluation method. Hence, the objective of this work is to produce highly porous AC from chickpea husks via chemical activation method and to evaluate it for heavy metal adsorption process in order to enhance the uptake amount of metals. Heavy metal adsorption experiments were performed at different $\mathrm{pH}$, initial metal concentration, AC dosage, temperature, and contact time.

\section{Materials and methods}

\section{Preparation and determination the main characteristics of raw material}

Waste chickpea (Cicer arietinum) husk was obtained from mid-Anatolia region. It was dried at room temperature, ground with a high-speed cutting mill and sieved prior to activation. A particle size range between 0.224 and $1.800 \mathrm{~mm}$ was used throughout the study. The proximate, ultimate, and structural analysis was performed to identify general characteristics and constituents of the biomaterial. Besides, thermogravimetric analysis (TGA) was performed in order to determine carbonization behavior of chickpea husks using a thermal analyzer (Seteram-LABSYS evo). TGA experiment was performed from room temperature to
$1000{ }^{\circ} \mathrm{C}$ using a ramping rate of $10{ }^{\circ} \mathrm{C} / \mathrm{min}$ under continuous $\mathrm{N}_{2}$ flow.

\section{Preparation of activated carbon}

$\mathrm{AC}$ is prepared by impregnating chickpea husk with ratios of $25,50,75$, and $100 \%$ by $\mathrm{KOH}$ and $\mathrm{K}_{2} \mathrm{CO}_{3}$ and keeping it in a hot air oven at $85^{\circ} \mathrm{C}$ for $72 \mathrm{~h}$ after keeping at room temperature for $24 \mathrm{~h}$. The samples of impregnated chickpea husk were placed in a stainless-steel reactor, and the activation temperature was set at $850{ }^{\circ} \mathrm{C}$ with a heating rate of $10{ }^{\circ} \mathrm{C} / \mathrm{min}$ under $\mathrm{N}_{2}$ gas flow $\left(100 \mathrm{~cm}^{3} / \mathrm{min}\right)$. The outlet gases were trapped in an ice-cooled bath, and the non-condensable gases were purged from the system. After the activation step, the solid carbonaceous residue is removed from the reactor and is washed with hot distilled water to remove the excess chemicals and dried at $105^{\circ} \mathrm{C}$. Samples are named according to the activating agent and impregnation ratio. For instance, AC1-25 belongs to the AC prepared by $\mathrm{K}_{2} \mathrm{CO}_{3}$ activation with an impregnation ratio of $25 \%$, whereas $\mathrm{AC} 2$ series denotes impregnation with $\mathrm{KOH}$.

\section{Characterization of activated carbons}

ACs are materials having complex porous structures with associated chemical inhomogeneity. Their structural heterogeneity is a result of the existence of a wide pore-size distributions including micropores, mesopores, and macropores of different sizes and shapes. Therefore, pore characteristics of ACs were determined by $\mathrm{N}_{2}$ adsorption at $-196{ }^{\circ} \mathrm{C}$ with a surface area and pore-size analyzer (Quantachrome Autosorb) in the first stage of characterization studies. Prior to $\mathrm{N}_{2}$ adsorption, $\mathrm{ACs}$ are degassed at $150{ }^{\circ} \mathrm{C}$ for at least $12 \mathrm{~h}$. Using BET equation, surface area of the carbons is determined, and the AC with the highest surface area is then characterized by pore-size distribution by quenched solid density functional theory (QSDFT).

Elemental composition of products and the raw material were determined by an elemental analyzer (Carlo Erba EA 1108 ) in order to find out elemental carbon content of the resultant products.

Microstructural evaluation of raw material and ACs were done by scanning electron microscopy and energy-dispersive $\mathrm{X}$-ray analysis (SEM-EDX). The morphological changes in the surface due to chemical activation were determined by SEM (Carl Zeiss Evo 50) using secondary electron images.

The $\mathrm{pH}$ of point of zero charge $\left(\mathrm{pH}_{\mathrm{pzc}}\right)$ of the $\mathrm{AC}$ was determined by preparing $50 \mathrm{~mL}$ solutions of $0.01 \mathrm{~N} \mathrm{NaCl}$ at different initial $\mathrm{pH}$ values between 2 and 12 by adding $0.01 \mathrm{~N} \mathrm{NaOH}$ or $\mathrm{HCl}$. An appropriate amount of AC (3 g/L) is added to the solutions and was placed on a shaker for $48 \mathrm{~h}$. Then, final $\mathrm{pH}$ of the solutions was measured and $\mathrm{pH}_{\mathrm{pzc}}$ of $\mathrm{AC}$ was noted as the point where $\mathrm{pH}_{\text {initial }}$ equals to $\mathrm{pH}_{\text {final }}$. 
Boehm titration was also performed to characterize surface chemistry of AC. $0.5 \mathrm{~g}$ of AC was placed into a series of flasks which include $50 \mathrm{ml}$ of $0.05 \mathrm{~N} \mathrm{NaHCO}_{3}$, $\mathrm{Na}_{2} \mathrm{CO}_{3}, \mathrm{NaOH}$ and $\mathrm{HCl}$.

Fourier transform infrared (FTIR) spectrum was collected in order to interpret functional groups of the AC using a Bruker Tensor 27 spectrophotometer. The materials were mixed with $\mathrm{KBr}$ powder and processed in pellets. The spectra were recorded in the range of $4000-400 \mathrm{~cm}^{-1}$.

\section{Batch adsorption experiments}

All chemicals used in batch adsorption studies were of analytical reagent grade and were used without further purification. Metal solutions were prepared by dissolving the appropriate amount of $\mathrm{Pb}\left(\mathrm{NO}_{3}\right)_{2}, \mathrm{Cu}\left(\mathrm{NO}_{3}\right)_{2} \cdot 3 \mathrm{H}_{2} \mathrm{O}$, and $\mathrm{K}_{2} \mathrm{Cr}_{2} \mathrm{O}_{7}$ in double-deionized water to prepare $1000 \mathrm{mg} / \mathrm{L}$ $\mathrm{Pb}(\mathrm{II}), \mathrm{Cu}(\mathrm{II})$, and $\mathrm{Cr}(\mathrm{VI})$ stock solutions, respectively. Then the required concentrations of experimental solutions were obtained by dilution. In order to adjust the $\mathrm{pH}$ $0.1 \mathrm{M} \mathrm{NaOH}$ or $\mathrm{HCl}$ solutions were used. All experiments were performed in batch mode $50-\mathrm{mL}$ sealed erlenmeyer flasks. During adsorption, the solution was stirred in a mechanical shaker where the temperature can be adjusted. When the residence time was over, AC was separated from the solution by filtering and the filtrate was analyzed using atomic adsorption spectrometer (Varian Spectraa 240FS). Experiments were performed in order to investigate the effects of $\mathrm{pH}(2-10)$, AC dose (2-6 g/L), initial metal ion concentration (100-400 mg/L), contact time (up to $360 \mathrm{~min})$, and temperature $\left(20-40{ }^{\circ} \mathrm{C}\right)$. The quantity of metal adsorbed per unit mass of AC at a specific time $\left(q_{t}\right)$ and equilibrium $\left(q_{e}\right)$ were calculated by using the following equations:

$q_{t}=\frac{\left(C_{i}-C_{t}\right)}{w} \times V$

$q_{e}=\frac{\left(C_{i}-C_{e}\right)}{w} \times V$

On the other hand, the percent adsorption of the metal ions was calculated as follows:

Adsorption $(\%)=\frac{\left(C_{i}-C_{e}\right)}{C_{i}} \times 100$

where $C_{i}$ is the initial metal concentration $(\mathrm{mg} / \mathrm{L}), C_{e}$ is the equilibrium metal concentration $(\mathrm{mg} / \mathrm{L}), C_{t}$ is the metal concentration at time $t(\mathrm{mg} / \mathrm{L}), V$ is the volume of solution $(\mathrm{L})$, and $w$ is the mass of the $\mathrm{AC} \mathrm{(g)} \mathrm{(Kilic} \mathrm{et} \mathrm{al.} \mathrm{2011;} \mathrm{Mashkoor}$ and Nasar 2019).

\section{Isotherm, kinetic and thermodynamic analysis of adsorption data}

\section{Equilibrium modeling}

Adsorption isotherms give qualitative information about the nature of the solute-surface interaction as well as the specific relation between the concentration of adsorbate and its degree of accumulation onto the surface at a specified temperature. For an appropriate design of sorption system, it is required to obtain an optimum correlation for the equilibrium curves, which can be defined as the relationships between the concentrations of the metal adsorbed and metal remaining in the solution at a specific temperature. For equilibrium modeling of the heavy metal adsorption on produced AC, Langmuir, Freundlich, Dubinin-Radushkevich (D-R), and Temkin isotherm models were used in the presented study.

The Langmuir isotherm relies on chemical and/or physical interactions between solute and vacant sites on the adsorbent surface. The linear form of the Langmuir equation is expressed as follows:

$\frac{C_{e}}{q_{e}}=\frac{1}{q_{m} K_{L}}+\frac{C_{e}}{q_{m}}$

where $q_{m}$ is the monolayer adsorption capacity of the AC $(\mathrm{mg} / \mathrm{g})$, and $K_{L}$ is the Langmuir adsorption constant $(\mathrm{L} / \mathrm{mg})$ that is related with the free energy of adsorption (Langmuir 1917,1918 ) With the help of dimensionless separation factor $\left(R_{L}\right)$, the affinity between the adsorbate and adsorbent can be predicted. $R_{L}$ is calculated by:

$R_{L}=\frac{1}{1+K_{L} C_{o}}$

where $C_{o}$ is the highest initial adsorbate concentration in the solution $(\mathrm{mg} / \mathrm{L})$. The value of $R_{L}$ shows that isotherm shape is either unfavorable $\left(R_{L}>1\right)$, linear $\left(R_{L}=1\right)$, favorable $\left(0<R_{L}<1\right)$ or irreversible $\left(R_{L}=0\right)$.

Contrary to Langmuir model, Freundlich assumes multilayer adsorbate uptake on the adsorbent surface (Freundlich 1906). The linearized Freundlich isotherm is represented by the following equation:

$\ln q_{e}=\ln K_{F}+\frac{1}{n} \ln C_{e}$

where $K_{F}\left((\mathrm{mg} / \mathrm{g})(\mathrm{L} / \mathrm{mg})^{1 / \mathrm{n}}\right)$ is a constant related with the adsorption capacity and $n$ is an empirical parameter indicating the adsorption intensity.

$\mathrm{D}-\mathrm{R}$ isotherm is another empirical isotherm model which is initially conceptualized for the sorption of subcritical vapors onto microporous sorbents according to pore filling mechanism (Tang et al. 2008). This model assumes a 
variable adsorption potential throughout a heterogeneous surface (Dubinin and Radushkevich 1947). The linear form of $\mathrm{D}-\mathrm{R}$ isotherm equation is as follows:

$\ln q_{e}=\ln q_{m}-\beta \varepsilon^{2}$

where $\beta$ is a constant related to the adsorption energy $\left(\mathrm{mol}^{2} /\right.$ $\left.\mathrm{kJ}^{2}\right), q_{m}$ is the theoretical saturation capacity, and $\varepsilon$ is the Polanyi potential and can be correlated as:

$\varepsilon=\mathrm{R} T\left[1+\frac{1}{C_{e}}\right]$

where $\mathrm{R}$ is the gas constant $(\mathrm{J} / \mathrm{mol} \mathrm{K})$ and $T$ is the absolute temperature $(\mathrm{K})$. And $\beta$ constant of $\mathrm{D}-\mathrm{R}$ equation gives the mean free energy $E(\mathrm{~kJ} / \mathrm{mol})=1 / \sqrt{2 \beta}$ of adsorption per molecule of the adsorbate when it is transferred to the surface of the solid from infinity in the solution and can be calculated by the following equation:

$E=\frac{1}{\sqrt{2 \beta}}$

The last isotherm model used in the study, Temkin (Temkin and Phyzev 1940a, b) considers the effects of indirect adsorbent/adsorbate interactions and assumes non-uniformly distributed binding energies of sorbate molecules. The linear form of Temkin isotherm equation is expressed as:

$q_{e}=B \ln K_{T}+B \ln C_{e}$

\section{Kinetic modeling}

In order to investigate adsorption mechanism and to calculate kinetic parameters, batch adsorption data were also analyzed by pseudo-first-order and pseudo-second-order and intraparticle diffusion and Elovich models.

The adsorption based on the sorption capacity of solids is mainly expressed by a pseudo-first-order kinetic model (Lagergren 1898) which assumes that one metal ion is sorbed onto one sorption site. The linearized pseudo-first-order rate equation of Lagergren based on solid capacity is formulized as follows:

$\log \left(q_{e}-q_{t}\right)=\operatorname{loq}\left(q_{e}\right)-\frac{k_{1} t}{2.303}$

where $q_{e}$ and $q_{t}$ are the adsorption capacity at equilibrium and at time $t(\mathrm{~min})$, respectively $(\mathrm{mg} / \mathrm{g}), k_{1}$ is the rate constant of pseudo-first-order adsorption ( $1 / \mathrm{min})$.

A pseudo-second-order equation (Ho and McKay 1999) to describe adsorption kinetics based on adsorption capacity may be expressed in the form of:

$\frac{t}{q_{t}}=\frac{1}{k_{2} q_{e}^{2}}+\frac{1}{q_{e}} t$ where $\mathrm{k}_{2}$ is the rate constant of pseudo-second-order adsorption ( $\mathrm{g} / \mathrm{mg} \mathrm{min})$.

Since pseudo-first-order and pseudo-second-order kinetic models cannot consider diffusion and rate-controlling steps in the transportation of sorbate molecules, intraparticle diffusion model (Weber and Morris 1963) is frequently preferred to fill this gap. The intraparticle diffusion equation can be written by the following:

$q_{t}=k_{p} t^{1 / 2}+C$

where $k_{p}$ is the intraparticle diffusion rate constant $\left(\mathrm{mg} / \mathrm{g} \mathrm{min}{ }^{1 / 2}\right.$ ) and $C$ is the intercept of intraparticle model plot. According to this model, the plot should be linear if intraparticle diffusion is involved in the adsorption process, and if these lines pass through the origin, then intraparticle diffusion is the rate-controlling step. In case the plot does not pass through the origin, some degree of boundary layer control is considered to exist. This indicates that intraparticle diffusion is not the only rate-limiting step, but also other kinetic models may control the rate of adsorption, because of their contribution to the overall transport of sorbate molecules (Chen et al. 2003).

Elovich kinetic model (Elovich and Larinov 1962) may be suitable when the adsorbate ions and the surface sites interact chemically through a second-order mechanism. The linear form of Elovich equation can be represented by:

$q_{t}=\frac{1}{\beta} \ln (\alpha \beta)+\frac{1}{\beta} \ln t$

\section{Thermodynamic modeling}

In order to understand the effect of temperature and conclude whether the adsorption process is spontaneous or not, thermodynamic parameters such as Gibbs free energy change $\left(\Delta G^{\circ}\right)$, enthalpy change $\left(\Delta H^{\circ}\right)$, and the entropy change $\left(\Delta S^{\circ}\right)$ were used extensively.

The Gibbs free energy change of the adsorption can be determined from the given equation:

$\Delta G^{o}=-\mathrm{R} T \ln K_{L}$

where $\mathrm{R}$ is gas constant $(8.314 \mathrm{~J} / \mathrm{mol} . \mathrm{K}), K_{L}$ is equilibrium constant and $T$ is absolute temperature $(\mathrm{K})$. The $K_{L}$ value was obtained using the following equation:

$K_{L}=\frac{q_{e}}{C_{e}}$

where $q_{e}$ and $C_{e}$ is the equilibrium concentration of metal ions on adsorbent $(\mathrm{mg} / \mathrm{g})$ and in the solution $(\mathrm{mg} / \mathrm{L})$, respectively. Relationship between $\Delta G^{\circ}, \Delta H^{\circ}$, and $\Delta S^{\circ}$ can be demonstrated by the following equation:

$\Delta G^{\circ}=\Delta H^{\circ}-T \Delta S^{\circ}$ 
And manipulation of Eq. 15 is resulted in a linear equation for calculating thermodynamic parameters as:

$\ln K_{L}=-\frac{\Delta G^{\circ}}{\mathrm{R} T}=-\frac{\Delta H^{\circ}}{\mathrm{R} T}+\frac{\Delta S^{\circ}}{\mathrm{R}}$

\section{Results and discussion}

\section{Thermogravimetric analysis}

In order to predict degradation behavior of chickpea husk and supply primary data for AC production, thermogravimetric analysis was performed, and results are given in Fig. 1. According to thermogram, thermal decomposition of material starts to be noticeable after about $150{ }^{\circ} \mathrm{C}$ and weight loss observed prior to this temperature corresponds to the moisture content of the husk. Main dTG peak around $320{ }^{\circ} \mathrm{C}$ indicates the temperature region in which carbonization reactions take place. Between 608 and $770{ }^{\circ} \mathrm{C}$, a reduced loss occurs, and no significant weight loss is observed above this region. Based on the literature survey, main constituents of lignocellulosic biomass (lignin, cellulose, and hemicellulose) degrade over a wide range of temperature. It is believed that hemicellulose degradation starts nearly at $200-260{ }^{\circ} \mathrm{C}$ and cellulose degradation occurs at around $240-350{ }^{\circ} \mathrm{C}$ due to the evolution of light volatile compounds from the structure. Since lignin is more thermostable than cellulose and hemicellulose, a wider temperature range lasting to $800{ }^{\circ} \mathrm{C}$ was expressed (González et al. 2009; Tongpoothorn et al. 2011). Thermal degradation behavior of chickpea husk employed in AC production showed typical characteristics of lignocellulosic biomass samples. According to the TG curve of chickpea husk, the activation temperature is chosen to be $850{ }^{\circ} \mathrm{C}$ where decomposition was about to fully completed.

\section{Product yield of activated carbons}

Product yield is crucial to determine the feasibility of AC production from a particular material. Therefore, product yields of produced carbons were calculated by dividing the weight of the resulting AC to the weight of chickpea husk used, and results are shown in Fig. 2. The relationship between product yield and impregnation ratio indicates that AC yield decreases with increasing the amount of activating agents at a fixed activation temperature. The effect of impregnation ratio may be attributed to increasing in effectiveness of activation process by the chemical agents due to burn-off. The highest AC yield was produced with an impregnation ratio of $25 \mathrm{wt} \%$ as 16.8 and $18.2 \mathrm{wt} \%$ for $\mathrm{KOH}$ and $\mathrm{K}_{2} \mathrm{CO}_{3}$ activation, respectively. Besides, the yields of ACs produced by $\mathrm{K}_{2} \mathrm{CO}_{3}$ activation were higher than those produces with $\mathrm{KOH}$ activation for all impregnation ratios. Similar results were obtained by several researchers (Ahmed and Theydan 2012; Foo and Hameed 2011), and the differences in product yields were explained due to the ability of $\mathrm{KOH}$ to remove more volatile materials during activation.

\section{Characterization of activated carbons}

Within the scope of this research, an attempt has been made to produce an AC with good adsorptive properties. As can be understood from the characteristics of raw chickpea husk (Table 1), it can be a good candidate for AC production due to its high carbon and low ash content.

$\mathrm{AC}$ produced with $\mathrm{KOH}$ activation with an impregnation ratio of $50 \mathrm{wt} \%$ has the highest BET surface area among the other products and is selected as the adsorbent for heavy metal removal experiments. In the literature, there is only one study on AC production from chickpea husk which was performed by Hayashi et al. (2002). They prepared AC from
Fig. 1 TG and dTG curves of raw chickpea husk

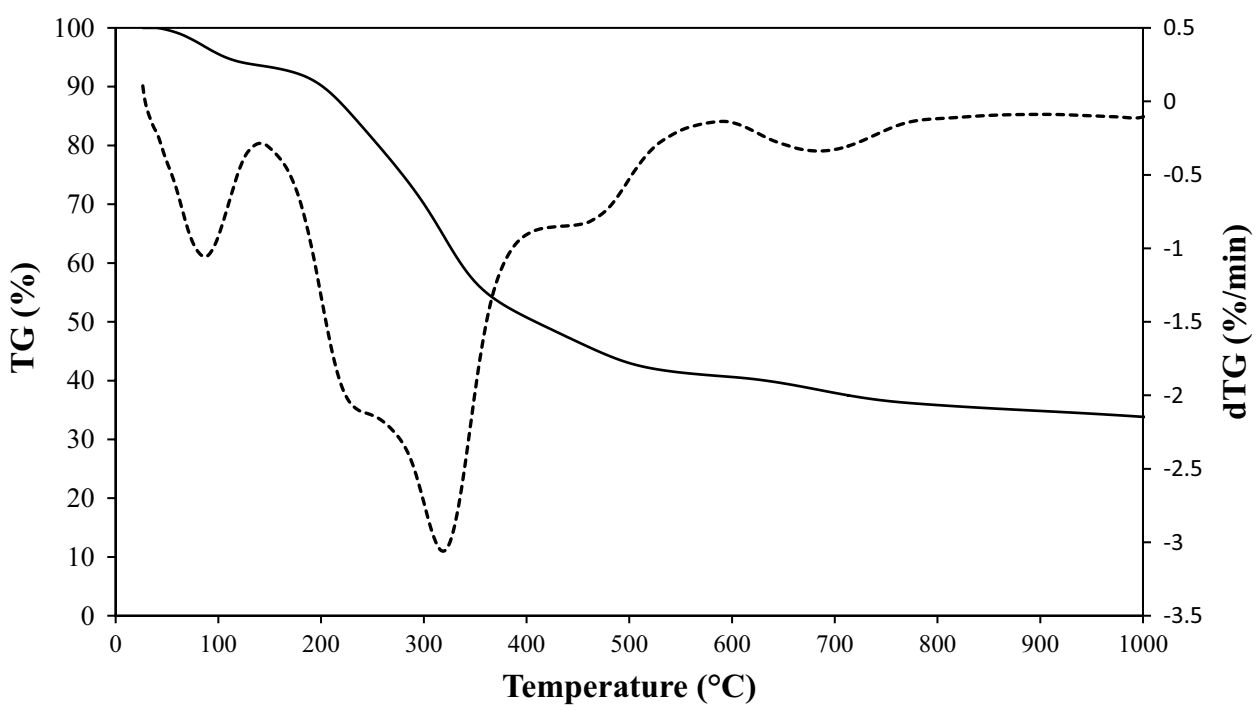



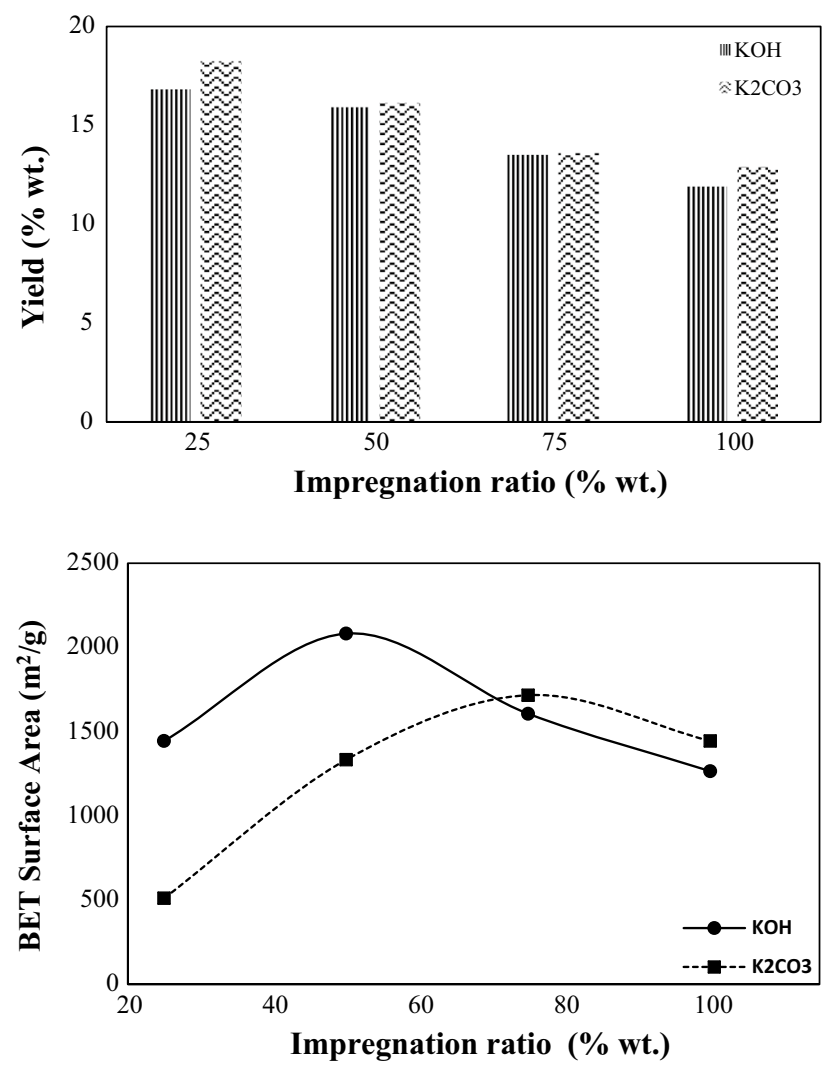

Fig. 2 Effect of impregnation ratio on activated carbon yield and BET surface area

Table 1 Characteristics of raw chickpea husk

\begin{tabular}{lr}
\hline Proximate analysis (\%) & \\
Moisture & 7.38 \\
Ash & 12.59 \\
Volatiles & 64.81 \\
Fixed C* & 15.22 \\
Ultimate analysis (\%) & \\
C & 49.01 \\
H & 4.02 \\
N & 6.25 \\
O* & 40.72 \\
Structural analysis (\%) & \\
Lignin & 17.78 \\
Extractives & 9.40 \\
Hemicellulose & 34.75 \\
Cellulose* & 38.07 \\
\hline
\end{tabular}

*From difference

chickpea husk by $\mathrm{K}_{2} \mathrm{CO}_{3}$ activation and obtained highest surface area as $1778 \mathrm{~m}^{2} / \mathrm{g}$ with an impregnation ratio of 1.0 $(100 \mathrm{wt} \%)$ and activation temperature of $800{ }^{\circ} \mathrm{C}$. Due to the lack of studies carried on the effect of the chemical agent, $\mathrm{KOH}$ activation was performed on the presented study, and it was understood that $\mathrm{KOH}$ activation of chickpea husks gives better results than $\mathrm{K}_{2} \mathrm{CO}_{3}$ activation in terms of BET surface area $\left(2082 \mathrm{~m}^{2} / \mathrm{g}\right)$. The pore characteristics, surface chemistry, and elemental composition of this product are summarized in Table 2. It is also concluded that both activation agent and impregnation ratio effects surface area significantly. The relationship between impregnation ratio and BET surface area is also investigated and given in Fig. 2. Accordingly, BET surface areas of both $\mathrm{KOH}$ and $\mathrm{K}_{2} \mathrm{CO}_{3}$ $\mathrm{AC}$ 's increased to some extent by increasing impregnation ratio. But BET surface area values are decreased after 50 and $75 \mathrm{wt} \%$ for $\mathrm{KOH}$ and $\mathrm{K}_{2} \mathrm{CO}_{3}$ impregnation, respectively. This may be due to the enhanced activation reactions which cause burn-off of the structure to form larger pores.

The reactions that leads the pore formation during $\mathrm{KOH}$ activation is believed to be related with gasification of carbonaceous materials by the following reactions:

$6 \mathrm{KOH}+2 \mathrm{C} \rightarrow 2 \mathrm{~K}+3 \mathrm{H}_{2}+2 \mathrm{~K}_{2} \mathrm{CO}_{3}$

Besides, $\mathrm{K}_{2} \mathrm{CO}_{3}$ activation is associated with the reactions given below:

$\mathrm{K}_{2} \mathrm{CO}_{3} \rightarrow \mathrm{K}_{2} \mathrm{O}+\mathrm{CO}_{2}$,

$\mathrm{K}_{2} \mathrm{O}+2 \mathrm{C} \rightarrow 2 \mathrm{~K}+\mathrm{CO}$.

It is considered that metallic potassium formed during the gasification process would diffuse into the internal carbon

Table 2 Pore characteristics, surface chemistry, and elemental composition of $\mathrm{KOH} \mathrm{AC}$

\begin{tabular}{|c|c|}
\hline \multicolumn{2}{|l|}{ Pore characteristics } \\
\hline BET surface area $\left(\mathrm{m}^{2} / \mathrm{g}\right)$ & 2082 \\
\hline Micropore volume $\left(\mathrm{cm}^{3} / \mathrm{g}\right)$ & 0.4814 \\
\hline Mesopore volume $\left(\mathrm{cm}^{3} / \mathrm{g}\right)$ & 0.6046 \\
\hline Total pore volume $\left(\mathrm{cm}^{3} / \mathrm{g}\right)$ & 1.0760 \\
\hline Micropore fraction (\%) & 44.74 \\
\hline Mesopore fraction (\%) & 52.26 \\
\hline External surface area $\left(\mathrm{m}^{2} / \mathrm{g}\right)$ & 1052 \\
\hline Average pore radius $(\AA)$ & 10.66 \\
\hline \multicolumn{2}{|l|}{ Surface chemistry } \\
\hline $\mathrm{pH}_{\mathrm{PZC}}$ & 7.85 \\
\hline Carboxylic surface functional groups (meq/g) & 0.4812 \\
\hline Lactonic surface functional groups (meq/g) & 0.3159 \\
\hline Phenolic surface functional groups (meq/g) & 1.0183 \\
\hline Total acidic functional groups (meq/g) & 1.0183 \\
\hline Total basic functional groups (meq/g) & 1.6806 \\
\hline \multicolumn{2}{|l|}{ Elemental composition } \\
\hline $\mathrm{C}(\mathrm{wt} \%)$ & 85.75 \\
\hline $\mathrm{H}(\mathrm{wt} \%)$ & 5.04 \\
\hline $\mathrm{N}(\mathrm{wt} \%)$ & 0.72 \\
\hline $\mathrm{O}^{*}(\mathrm{wt} \%)$ & 8.49 \\
\hline
\end{tabular}

*From difference 
matrix and hence widen the existing pores and/or create new pores in the structure. By this way, $\mathrm{KOH}$ activation may result in higher surface area than $\mathrm{K}_{2} \mathrm{CO}_{3}$ activation because of the quantity of evolved metallic potassium during activation (Ahmed and Theydan 2012).

For the sake of comparison, the BET values of some biomass-based AC available in the literature are also given in Table 3. Differences of BET surface areas undoubtedly affected both process conditions employed such as impregnation ratio, activation temperature, and precursor characteristics. As it can be seen, the porous structure of the carbon obtained in this work is compatible with the ACs that were produced with different biomaterials, activating agents, and methods.

$\mathrm{N}_{2}$ adsorption-desorption isotherm of $\mathrm{KOH}$ AC (AC2$50)$ is given in Fig. 3 to explain general features of AC. Accordingly, the initial part of the isotherm is of type I with significant uptake at low relative pressures, which corresponds to a microporous structure. At intermediate and high relative pressures, the isotherm shape can be described by type IV with an $\mathrm{H} 4$ type of hysteresis loop which indicates the existence of mesopores and slit-shaped pores.

To specify the fraction of the surface that an adsorbate molecule can access and cover the surface, pore-size distribution (PSD) of AC was determined by density functional theory (DFT). Since recently developed QSDFT method considers the chemical and geometrical heterogeneity of the pore walls, assuming a structureless, chemically and geometrically smooth surface (Neimark et al. 2009). PSD of AC was determined for slit pore-shaped ACs, and it is also given in Fig. 3. According to the classification of IUPAC, the pores of materials could be classified into micropores $(d<2 \mathrm{~nm})$, mesopores $(d=2-50 \mathrm{~nm})$, and macropores $(d>50 \mathrm{~nm})$. PSD showed that the produced AC had a bimodal PSD which is highly microporous. Also PSD obtained with an actual fitting error of $0.49 \%$ indicated the consistency between the gas adsorption data and DFT method. Table 2 also reports detailed pore characteristics of the AC to determine micropore and mesopore distribution. Approximately, the contribution of micropore volume was obtained as $45 \%$ of the total pore volume, and average pore radius was found as $10.66 \AA$.

SEM technique was used to observe the surface morphologies of the chickpea husk and derived ACs. The microstructure of raw chickpea straw, and the resulting $\mathrm{KOH}$ and $\mathrm{K}_{2} \mathrm{CO}_{3} \mathrm{AC}$ are shown in Fig. 4. According to the obtained micrographs, there were significant differences between the surface topography of raw husk and produced carbons. Raw chickpea husk exhibited a non-porous fibrous morphology. On the other hand, ACs prepared with both $\mathrm{KOH}$ and $\mathrm{K}_{2} \mathrm{CO}_{3}$ have a sponge-like porous structure with interconnected channels. Because activating agents leaving from the structure results in the open spaces that were previously occupied by them. Also, agents decomposing at higher temperatures which in turn cause the burn-off of the carbon structure resulting in a porous texture.

Elemental analysis results of ACs showed that carbonization of husks caused increases in elemental carbon contents. Elemental carbon contents were also verified with SEM-EDX analysis (Fig. 5). According to the EDX analysis, $\mathrm{KOH} \mathrm{AC}$ with the highest surface area had $84.2 \mathrm{wt} \%$ carbon and 15.4 oxygen wt $\%$ in the structure, while $\mathrm{K}_{2} \mathrm{CO}_{3}$

Table 3 BET surface areas of different biomass-based activated carbons

\begin{tabular}{|c|c|c|c|c|c|}
\hline Raw material & Activation agent & $\begin{array}{l}\text { Impregnation ratio } \\
\text { (wt\%/wt reagent) }\end{array}$ & $\begin{array}{l}\text { Activation tem- } \\
\text { perature }\left({ }^{\circ} \mathrm{C}\right)\end{array}$ & $\begin{array}{l}\text { BET surface } \\
\text { area }\left(\mathrm{m}^{2} / \mathrm{g}\right)\end{array}$ & References \\
\hline \multirow[t]{2}{*}{ Cotton stalk } & $\mathrm{KOH}$ & 1.25 & N/A & 729 & Deng et al. (2010) \\
\hline & $\mathrm{K}_{2} \mathrm{CO}_{3}$ & & & 621 & \\
\hline Bamboo waste & $\mathrm{KOH}$ & 2.0 & 800 & 1533 & Hirunpraditkoon et al. (2011) \\
\hline Hemp stem & $\mathrm{KOH}$ & 0.22 & 800 & 3241 & Yang et al. (2012) \\
\hline Wood sawdust & $\mathrm{K}_{2} \mathrm{CO}_{3}$ & 1.25 & 700 & 1496 & Foo and Hameed (2012) \\
\hline \multirow[t]{2}{*}{ Tobacco stem } & $\mathrm{KOH}$ & 0.5 & 600 & 500 & Chen et al. (2017) \\
\hline & $\mathrm{K}_{2} \mathrm{CO}_{3}$ & 4.0 & & 553 & \\
\hline Waste tea & $\mathrm{K}_{2} \mathrm{CO}_{3}$ & 1.00 & 900 & 1772 & Gurten et al. (2012) \\
\hline Rice husk & $\mathrm{KOH}$ & 5.00 & 850 & 2696 & Muniandy et al. (2014) \\
\hline Mangosteen shells & $\mathrm{K}_{2} \mathrm{CO}_{3}$ & 1.00 & 900 & 1123 & Chen et al. (2011) \\
\hline \multirow[t]{2}{*}{ Hazelnut shells } & $\mathrm{KOH}$ & 2.0 & 900 & 2319 & Kwiatkowski and Broniek (2017) \\
\hline & $\mathrm{K}_{2} \mathrm{CO}_{3}$ & & & 887 & \\
\hline \multirow[t]{2}{*}{ Grape seeds } & $\mathrm{KOH}$ & 1.00 & 800 & 1222 & Okman et al. (2014) \\
\hline & $\mathrm{K}_{2} \mathrm{CO}_{3}$ & 0.25 & 800 & 1238 & \\
\hline \multirow[t]{2}{*}{ Chickpea husk } & $\mathrm{KOH}$ & 0.50 & 850 & 2082 & This study \\
\hline & $\mathrm{K}_{2} \mathrm{CO}_{3}$ & 1.00 & 850 & 1921 & \\
\hline
\end{tabular}




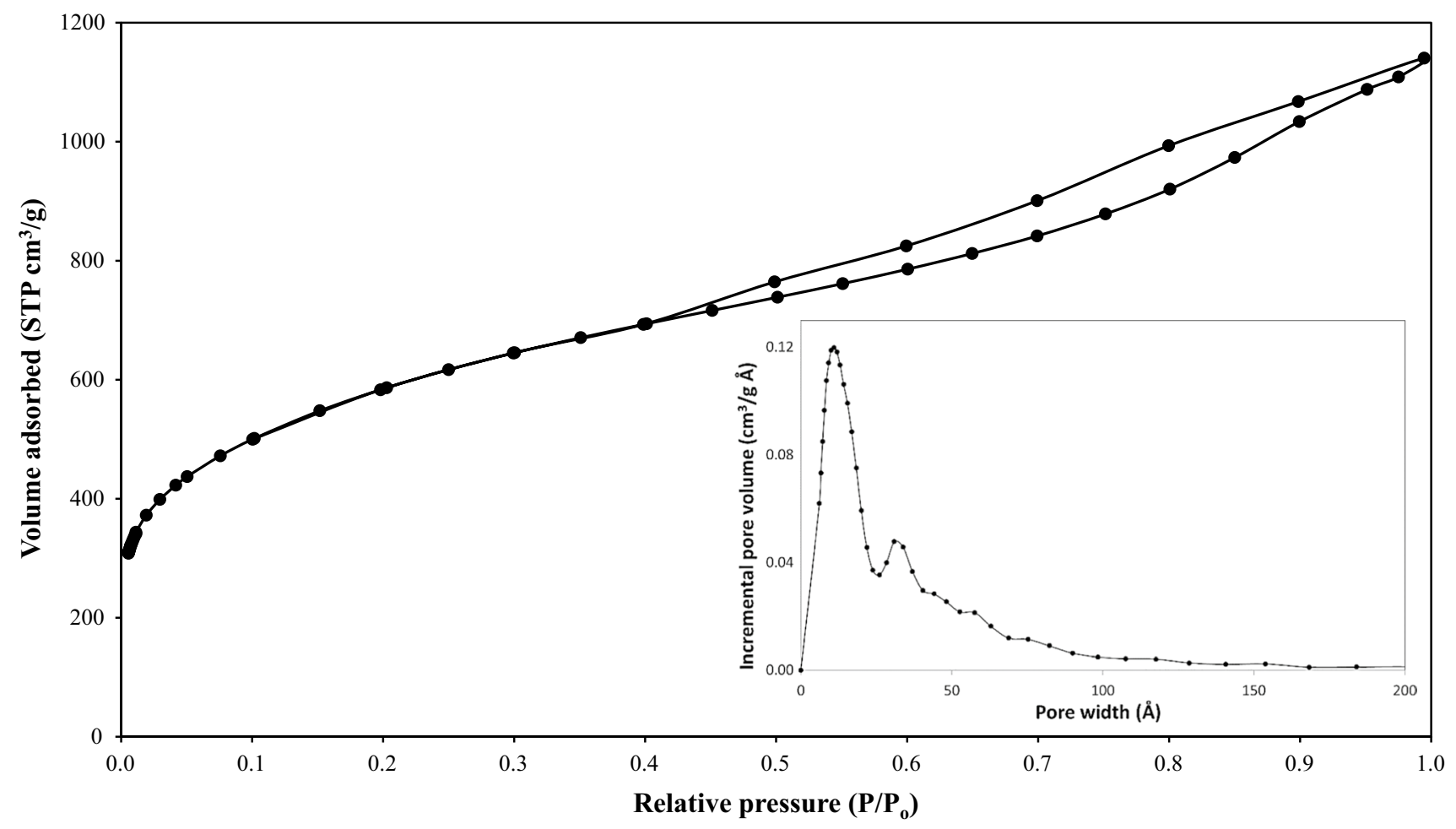

Fig. $3 \mathrm{~N}_{2}$ adsorption-desorption isotherm and pore-size distribution of $\mathrm{KOH}$ activated carbon (AC2-50)

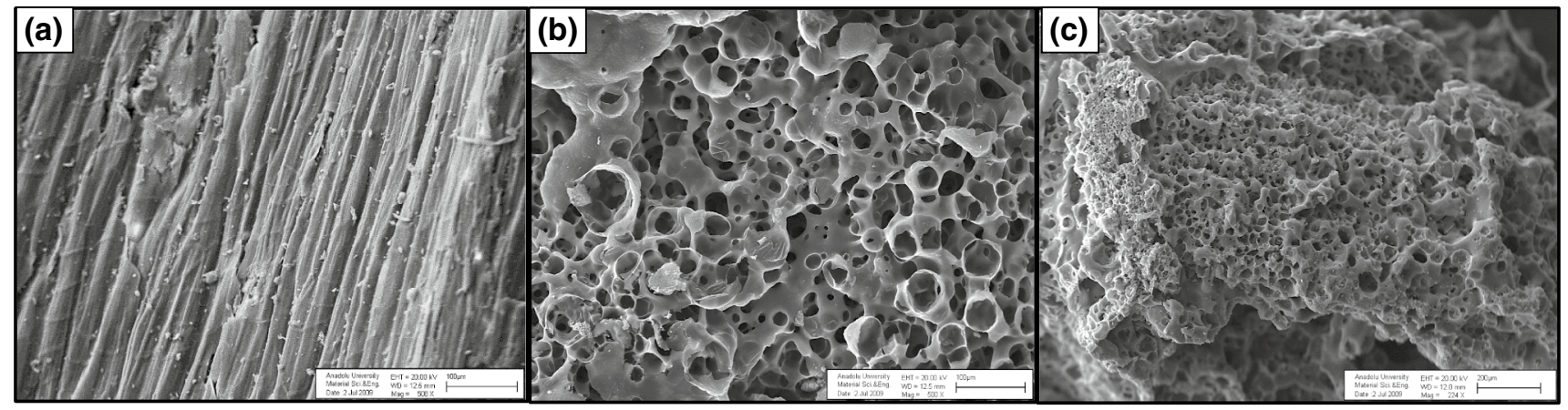

Fig. 4 SEM images of a raw chickpea straw, b $\mathrm{KOH}$ activated carbon, $\mathbf{c} \mathrm{K}_{2} \mathrm{CO}_{3}$ activated carbon

AC had $83.5 \mathrm{wt} \%$ and $15.9 \mathrm{wt} \%$ carbon and oxygen contents, respectively.

Like the textural properties, surface chemistry also affects the applicability of ACs. AC can be defined as a twisted network of defective hexagonal carbon layer planes. These layer planes are cross-linked by aliphatic bridging groups, and heteroatoms on the surface of AC have a significant key role in the surface chemistry by influencing the adsorbent-adsorbate interactions. In order to assess basic and acidic surface functional groups of ACs, Boehm titration is a widely used technique. The acidic groups of AC surface are carboxyl, lactone, hydroxyl, and carbonyl oxygen functionalities, while the postulated basic surface groups are chromene-type structures and pyrone-type oxides (Rakić et al. 2015). $\mathrm{pH}_{\mathrm{PZC}}$ is also determined for $\mathrm{KOH} \mathrm{AC}$ and given in Table 2. $\mathrm{pH}_{\mathrm{PZC}}$ is defined as the $\mathrm{pH}$ at which carbon surface has no charge, namely the zeta $(\zeta)$ potential is zero. The density of electrical charge is obtained as zero at an approximate $\mathrm{pH}$ value of 8 for $\mathrm{KOH} \mathrm{AC}$. That means basic surface functional groups are mainly located on the surface of $\mathrm{KOH} \mathrm{AC}$. This indicates that the surface groups are mainly related to the impregnation agent and its relative amount. On the other hand, acidic groups of produced AC are mainly carboxylic groups which were $0.4812 \mathrm{meq} / \mathrm{g}$. It is widely accepted that these carboxyl groups are responsible for heavy metal sorption. Since carboxylic groups 


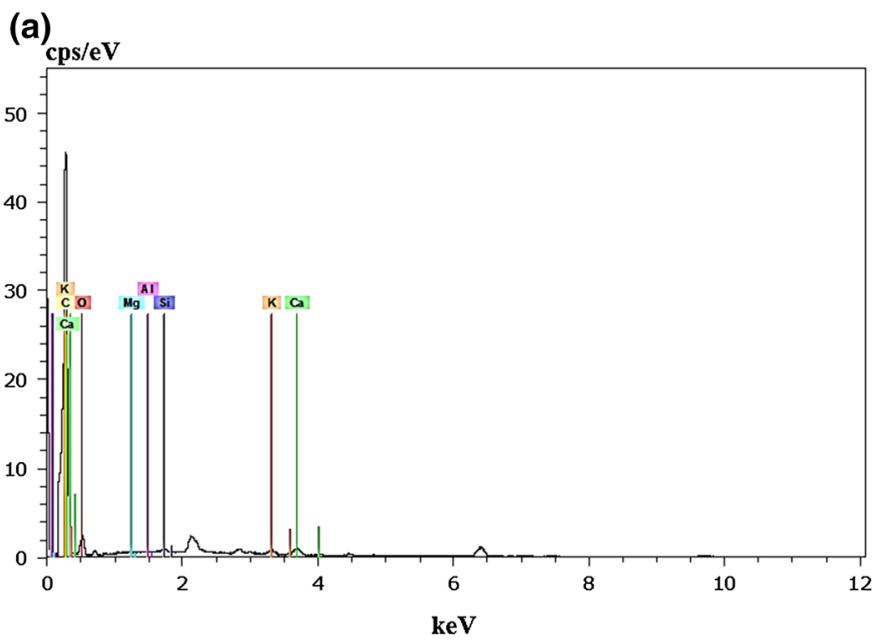

(b)

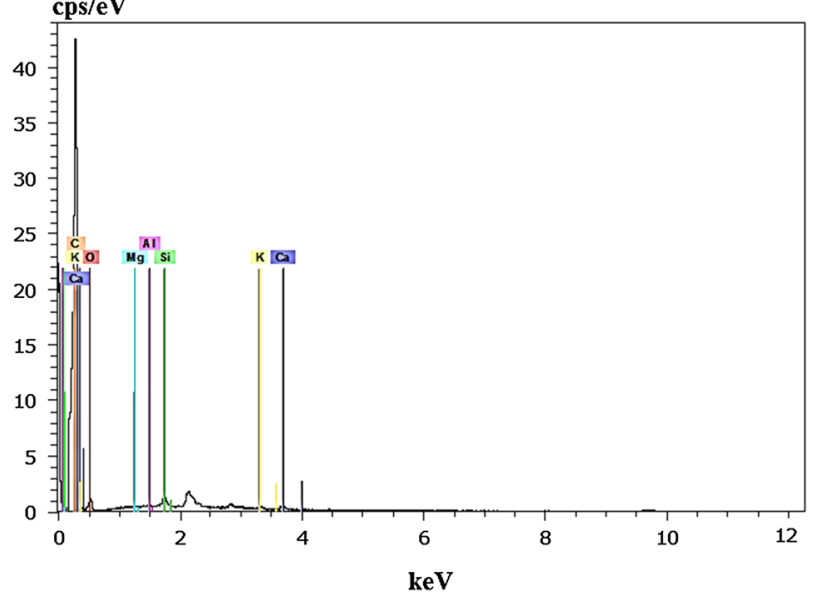

Fig. 5 EDX spectra of $\mathrm{KOH}(\mathbf{a})$ and $\mathrm{K}_{2} \mathrm{CO}_{3}$ (b) ACs

on the surface of AC promotes an enhanced acidic dissociation and chelating attributes that form complexes of the adsorbed metal and functional groups. The FTIR spectrum of $\mathrm{KOH} \mathrm{AC}$ and the bands corresponding to the main functional groups are shown in Fig. 6. The broad peak between 3300 and $3400 \mathrm{~cm}^{-1}$ was due to the stretching vibrations of the $\mathrm{O}-\mathrm{H}$ bonds of water molecules which were adsorbed onto the matrices of the AC. The band around 1100 and $1000 \mathrm{~cm}^{-1}$ was because of $\mathrm{C}-\mathrm{O}$ stretching vibrations. On the other hand, the band between 1500 and $1600 \mathrm{~cm}^{-1}$ can be ascribed to $\mathrm{C}=\mathrm{C}$ aromatic ring stretching vibration which can be also observed by the help of a weaker band between 765 and $530 \mathrm{~cm}^{-1}$ (Kılıç et al. 2012; Valizadeh et al. 2016).

\section{Heavy metal adsorption}

Produced AC with the highest BET surface area (AC250 ) is used in the adsorption experiments. An adsorption study of $\mathrm{Pb}(\mathrm{II}), \mathrm{Cu}(\mathrm{II})$, and $\mathrm{Cr}(\mathrm{VI})$ ions was performed by first investigating the effect of different factors such as $\mathrm{pH}$, adsorbent dose, concentration, temperature, and contact time. After that, a systematic data analysis for equilibrium, kinetic, and thermodynamic modeling was carried out in order to determine the feasibility of use of chickpea-huskderived $\mathrm{AC}$ as an adsorbent.

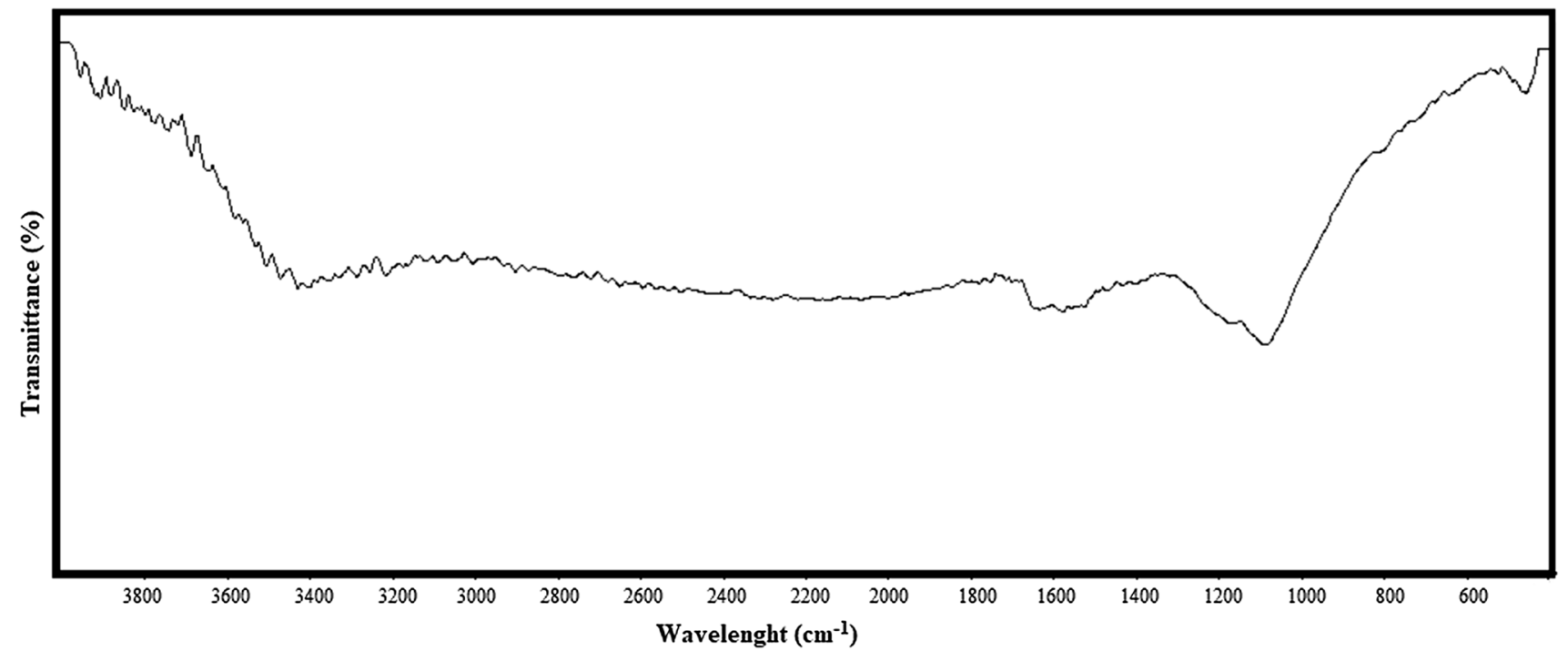

Fig. 6 FTIR spectrum of $\mathrm{KOH}$ activated carbon (AC2-50) 


\section{Effect of $\mathrm{pH}$}

In the adsorption of metal ions, hydrogen ion concentration of the solution is an important factor that should be considered. $\mathrm{pH}$ affects the solubility of the metal ions in the solution and replaces some of the positive ions found in the active sites and the degree of ionization of the adsorbate. Therefore, the effect of $\mathrm{pH}$ was examined from solutions at different $\mathrm{pH}$ values ranging from 2 to 10 to obtain maximum removal efficiencies. To optimize $\mathrm{pH}$, adsorbent dose $(0.1$ grams of AC), initial metal concentration $(100 \mathrm{mg} / \mathrm{L})$, and contact time $(1 \mathrm{~h})$ parameters are kept constant.

The $\mathrm{pH}$ value, at which the amount of positive and negative groups is equal, was estimated as the point of zero charge $\left(\mathrm{pH}_{\mathrm{PZC}}\right)$. The $\mathrm{pH}_{\mathrm{PZC}}$ of $\mathrm{AC}$ showed that the surface is positively charged at $\mathrm{pH}$ values less than $\mathrm{pH}_{\mathrm{PZC}}$ and negatively charged at $\mathrm{pH}$ values higher $\mathrm{pH}_{\mathrm{PZC}}$.

The adsorption of cations, such as metal ions, is favored at $\mathrm{pH}>\mathrm{pH}_{\mathrm{PZC}}$, while the adsorption of anions is favored at $\mathrm{pH}<\mathrm{pH}_{\mathrm{PZC}}$, due to electrostatic repulsion (Cechinel and de Souza; 2014). As it can be seen from Fig. 7 at lower pH values, there are more protons on the carbon surface that compete with metal ions in the solution. As $\mathrm{pH}$ increased $\mathrm{Pb}(\mathrm{II})$, $\mathrm{Cu}(\mathrm{II})$ and $\mathrm{Cr}(\mathrm{VI})$ adsorption was increased until a $\mathrm{pH}$ value of 9. At $\mathrm{pH}$ values greater than 9, heavy metal adsorption decreased which may be attributed to the association or dissociation of surface functional groups. Also, increasing $\mathrm{pH}$ from 8 to 9 did not considerably changed uptake values, and keeping this in view, the $\mathrm{pH}$ values of solutions have been kept constant at a value of 8 in all the subsequent studies.

\section{Effect of adsorbent dose}

Since adsorbent dosage determines the capacity of an adsorbent for a specified initial concentration of adsorbate, effect of AC amount on heavy metal adsorption is investigated. It is known that as the amount of adsorbent is increased, the

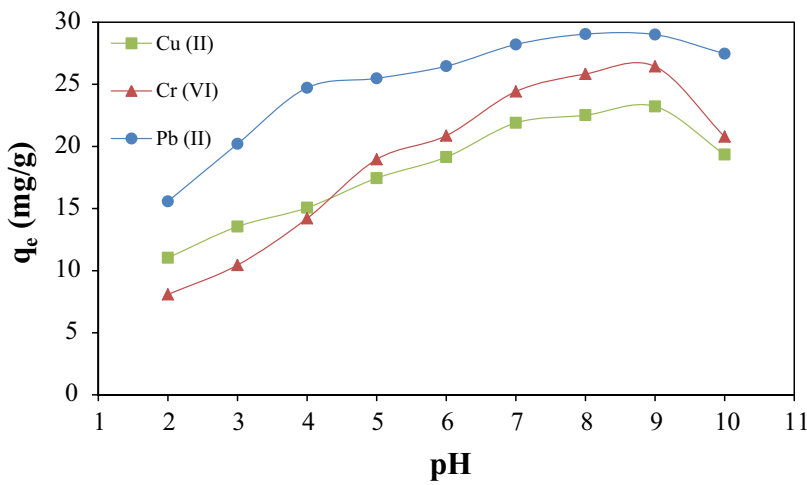

Fig. 7 Effect of solution $\mathrm{pH}$ on uptake amounts of $\mathrm{Cu}$ (II), $\mathrm{Cr}(\mathrm{VI})$ and $\mathrm{Pb}(\mathrm{II})$ adsorption sites remain unsaturated during the adsorption reaction causing to decrease in adsorption capacity (Hameed et al. 2017). But, the aggregation/agglomeration of adsorbent particles at higher dose would cause a decrease in the available surface area and an increase in the diffusional path length. Figure 8 shows the removal of $\mathrm{Cu}(\mathrm{II}), \mathrm{Pb}(\mathrm{II})$, and $\mathrm{Cr}(\mathrm{VI})$ as a function of carbon dosage. Increasing carbon dosage resulted in a decline in the amount of adsorbed metal. Optimum adsorbent dosages were determined as $2 \mathrm{~g} / \mathrm{L}$ for $\mathrm{Pb}(\mathrm{II})$, whereas $3 \mathrm{~g} / \mathrm{L} \mathrm{g}$ for $\mathrm{Cr}(\mathrm{VI})$ and $\mathrm{Cu}(\mathrm{II})$, and these optimum values used at the remaining part of the study.

\section{Effect of concentration, temperature, and contact time for $\mathrm{Pb}(\mathrm{II}), \mathrm{Cu}(\mathrm{II})$, and $\mathrm{Cr}(\mathrm{VI})$ sorption}

The results of for $\mathrm{Pb}(\mathrm{II}), \mathrm{Cu}$ (II), and $\mathrm{Cr}(\mathrm{VI})$ sorption indicate that increase in the concentration of adsorbate increased the amount of metal ion adsorbed per gram of AC. To put it other words, higher concentration implies more metal ions fixed on the surface of the adsorbent (Akpomie et al. 2018). A possible explanation may be that increasing the concentration of metal ions in solution causes an increase in mass transfer due to the increment of driving force for the transportation of ions from solution to the carbon surface (Tan et al. 2016). Figure 9 is used for explaining the contact time and temperature dependency of uptake amounts in the case of $400 \mathrm{mg} / \mathrm{L}$ initial metal ion concentration. It is observed from the figure that adsorption was fast as most of the surface of AC was not saturated with metal ions. Hence adsorption rate was fast initially and then slowed down gradually due to saturation. Finally, an equilibrium between adsorbate and adsorbent surface was established after $90 \mathrm{~min}$ for $\mathrm{Pb}(\mathrm{II}), \mathrm{Cu}(\mathrm{II})$, and $\mathrm{Cr}(\mathrm{VI})$ ions. It is revealed that there was no considerable change after these periods for all initial concentrations. To determine the effect of temperature, the adsorption of $\mathrm{Pb}(\mathrm{II}), \mathrm{Cu}(\mathrm{II})$, and $\mathrm{Cr}(\mathrm{VI})$ on $\mathrm{AC}$ was also studied at temperatures of 20,30 , and $40{ }^{\circ} \mathrm{C}$, and it is found

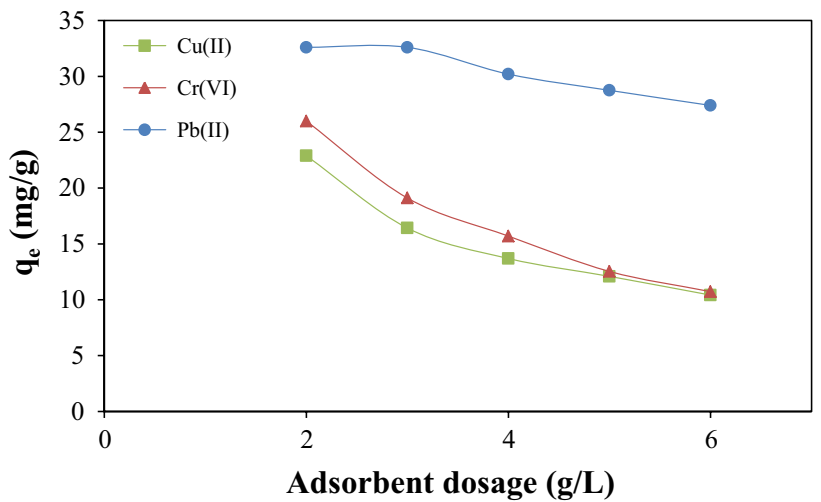

Fig. 8 Effect of adsorbent dosage on uptake amounts of $\mathrm{Cu}$ (II), $\mathrm{Cr}(\mathrm{VI})$ and $\mathrm{Pb}(\mathrm{II})$ 

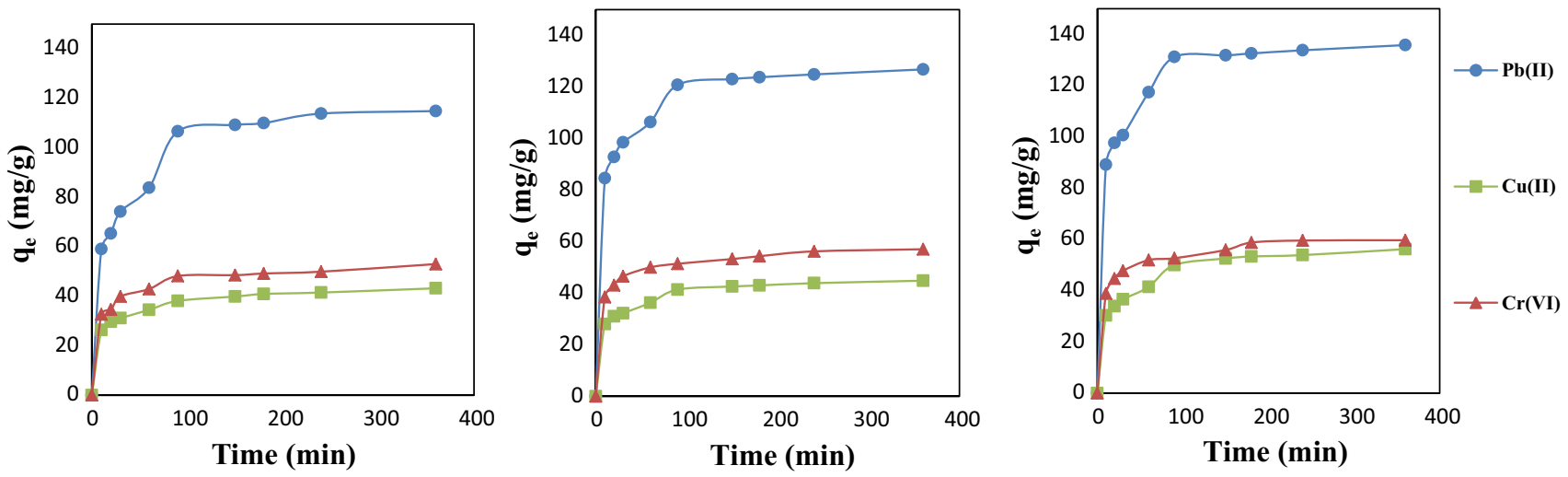

Fig. $9 \mathrm{Cu}(\mathrm{II}), \mathrm{Cr}(\mathrm{VI})$, and $\mathrm{Pb}(\mathrm{II})$ uptake at different, contact time and temperature (initial metal ion concentration $=400 \mathrm{mg} / \mathrm{L}$ )

that the adsorption capacity of ions increased at higher temperatures. Temperature has a slightly increasing effect of adsorption capacity for $\mathrm{Cr}(\mathrm{VI})$ and $\mathrm{Cu}(\mathrm{II})$ ions. The effect of temperature is much more apparent in the $\mathrm{Pb}$ (II) removal curves. These may be attributed to the endothermic nature of adsorption of $\mathrm{Pb}(\mathrm{II}), \mathrm{Cu}(\mathrm{II})$, and $\mathrm{Cr}(\mathrm{VI})$ onto chickpeahusk-derived AC as will be further supported by a thermodynamic analysis. At the conditions employed, maximum adsorption capacity obtained at $40{ }^{\circ} \mathrm{C}, 400 \mathrm{mg} / \mathrm{L}$ initial metal concentration and $360 \mathrm{~min}$ contact time was found to be $135.8,59.6$, and $56.2 \mathrm{mg} / \mathrm{g}$ for $\mathrm{Pb}(\mathrm{II}), \mathrm{Cr}(\mathrm{VI})$, and $\mathrm{Cu}(\mathrm{II})$, respectively. In a study that was performed by Alhashimi and Aktas (2017), different types of commercial ACs were performed in order to make a comparison among the different kinds of commercial and produced $\mathrm{AC}$ and bio-char samples. Accordingly, adsorption capacity for $\mathrm{Cu}(\mathrm{II})$ ions were between 1.8 and $30.1 \mathrm{mg} / \mathrm{g}$, while it was between 4.7 and $53.2 \mathrm{mg} / \mathrm{g}$ for $\mathrm{Cr}(\mathrm{IV})$. On the other hand, the adsorption capacity of commercial ACs toward to $\mathrm{Pb}$ (II) reached higher values up to $81.9 \mathrm{mg} / \mathrm{g}$. By doing a detailed analysis considering both economic and environmental factors together with adsorption capacities, they concluded that engineered AC and bio-char products should be optimized for adsorption applications. The maximum adsorption capacities of chickpea-husk-based $\mathrm{AC}$ toward to $\mathrm{Pb}(\mathrm{II}), \mathrm{Cr}(\mathrm{VI})$, and $\mathrm{Cu}(\mathrm{II})$ ions show that AC2-50 can provide a potentially replacement of commercial ACs.

\section{Adsorption Isotherms}

Sorption equilibria provide fundamental physiochemical data for evaluating the applicability of the sorption process as a unit operation. The performance of produced $\mathrm{AC}$ at different temperatures was evaluated by Langmuir, Freundlich, D-R, and Temkin adsorption models and isotherm parameters of models obtained by using nonlinear regression given in Table 4. Among all the models applied,
Table 4 Isotherm constants obtained for heavy metal adsorption at $20{ }^{\circ} \mathrm{C}$

\begin{tabular}{llll}
\hline Isotherms & $\mathrm{Pb}(\mathrm{II})$ & $\mathrm{Cu}(\mathrm{II})$ & $\mathrm{Cr}(\mathrm{VI})$ \\
\hline Langmuir & & & \\
$q_{m}(\mathrm{mg} / \mathrm{g})$ & 125.0001 & 41.6667 & 126.5823 \\
$K_{L}(\mathrm{~L} / \mathrm{mg})$ & 0.0264 & 0.0340 & 0.0265 \\
$R^{2}$ & 0.9575 & 0.9947 & 0.9575 \\
Freundlich & & & \\
$K_{F}\left((\mathrm{mg} / \mathrm{g})(\mathrm{L} / \mathrm{mg})^{1 / \mathrm{n}}\right)$ & 18.7595 & 11.6581 & 0.7781 \\
$n$ & 3.1094 & 4.8076 & 1.3586 \\
$R^{2}$ & 0.9687 & 0.9970 & 0.9837 \\
Dubinin-Radushkevich & & & \\
$q_{m}(\mathrm{mg} / \mathrm{g})$ & 85.6526 & 34.7403 & 39.8531 \\
$\beta$ & $2.0 \times 10^{-5}$ & $6.0 \times 10^{-5}$ & $5.0 \times 10^{-4}$ \\
$E$ & $1.50 \times 10^{2}$ & $0.913 \times 10^{2}$ & $0.316 \times 10^{2}$ \\
$R^{2}$ & 0.7420 & 0.8227 & 0.7983 \\
Temkin & & & \\
$B$ & 22.3040 & 6.2648 & 18.469 \\
$K_{T}$ & 0.4731 & 1.3978 & 0.0217 \\
$R^{2}$ & 0.9119 & 0.9844 & 0.9248 \\
\hline
\end{tabular}

best fitting with the experimental data was obtained by Freundlich adsorption isotherm model which has the highest regression $\left(R^{2}\right)$ coefficients. Obtaining best fitting with Freundlich model supports surface heterogeneity of $\mathrm{AC}$ and an exponential distribution of the active sites and their energies. The isotherm parameters of $\mathrm{n}$ in Freundlich model were found to be greater than 1 which indicates that the adsorption of metal ions onto $\mathrm{AC}$ is a favorable process (Kataria and Garg 2018; Wang et al. 2018). $K_{F}$ parameter may also considered as an indicator of the adsorption capacity, and it was found higher in the case of $\mathrm{Pb}$ (II) adsorption. According to the Langmuir isotherm parameters, adsorption tendency of $\mathrm{Pb}(\mathrm{II})$ ions is found more than $\mathrm{Cr}(\mathrm{VI})$ and $\mathrm{Cu}(\mathrm{II})$. 


\section{Adsorption kinetics}

Adsorption kinetics supply significant information about the reaction pathways and controlling mechanism of adsorption process, which in turn governs mass transfer and the residence time. Kinetic analysis was conducted over a broad temperature and initial metal concentration range, and similar results were obtained. For this reason, kinetic parameters calculated at $20^{\circ} \mathrm{C}$ and $400 \mathrm{mg} / \mathrm{L}$ initial metal concentration to demonstrate the overall results are reported in Table 5 . The conformity between experimental data obtained and the model predicted values was decided according to correlation coefficients $\left(R^{2}\right)$. Analysis of the regression coefficients indicated that the pseudo-second-order kinetic model fitted very well with the dynamical behavior for the adsorption of $\mathrm{Pb}(\mathrm{II}), \mathrm{Cu}(\mathrm{II})$, and $\mathrm{Cr}(\mathrm{VI})$ ions on chickpea-husk-derived $\mathrm{AC}$ under different initial metal ion concentrations. This states that the rate-limiting step on the transportation of metal ions to the solid surface may be chemical sorption rather than diffusion (Abbas et al. 2014; Semerjian 2018). The rate constants for $\mathrm{Pb}(\mathrm{II}), \mathrm{Cr}(\mathrm{VI})$, and $\mathrm{Cu}(\mathrm{II})$ adsorption were calculated as $0.0015,0.0040$, and $0.0057 \mathrm{~g} / \mathrm{mg}$ min, respectively.

\section{Adsorption thermodynamics}

The thermodynamic parameters of adsorption provide indepth information about the nature of the process. Therefore, the change in Gibbs free energy $\left(\Delta G^{\circ}\right)$, enthalpy $\left(\Delta H^{\circ}\right)$, and entropy $\left(\Delta S^{\circ}\right)$ values of $\mathrm{Pb}(\mathrm{II}), \mathrm{Cu}(\mathrm{II})$, and $\mathrm{Cr}(\mathrm{VI})$ adsorption is given in Table 6. Accordingly, all of the calculated adsorption enthalpies for of $\mathrm{Pb}(\mathrm{II}), \mathrm{Cu}(\mathrm{II})$, and $\mathrm{Cr}(\mathrm{VI})$

Table 5 Kinetic parameters calculated at $20{ }^{\circ} \mathrm{C}$ and $400 \mathrm{mg} / \mathrm{L}$ initial metal concentration

\begin{tabular}{lrrr}
\hline Kinetic model & $\mathrm{Pb}(\mathrm{II})$ & $\mathrm{Cr}(\mathrm{VI})$ & $\mathrm{Cu}(\mathrm{II})$ \\
\hline Pseudo-first-order & & & \\
$k_{1}$ & 0.0147 & 0.0223 & 0.0230 \\
$q_{e}$ & 54.0629 & 19.0633 & 14.0507 \\
$R^{2}$ & 0.9802 & 0.9431 & 0.9919 \\
Pseudo-second-order & & & \\
$k_{2}$ & 0.0015 & 0.0040 & 0.0057 \\
$q_{e}$ & 93.4579 & 46.5116 & 37.0370 \\
$R^{2}$ & 0.9970 & 0.9973 & 0.9989 \\
Intraparticle diffusion & & & \\
$k_{p}$ & 5.5229 & 2.3527 & 1.7255 \\
$C$ & 41.8400 & 25.2520 & 21.4360 \\
$R^{2}$ & 0.9428 & 0.9281 & 0.9784 \\
Elovich & & & \\
$\alpha$ & 82.2342 & 118.1455 & 159.5294 \\
$\beta$ & 0.0703 & 0.1643 & 0.2223 \\
$R^{2}$ & 0.9770 & 0.9326 & 0.9976 \\
\hline
\end{tabular}

Table 6 Calculated thermodynamic parameters for heavy metal adsorption

\begin{tabular}{llllll}
\hline & $T\left({ }^{\circ} \mathrm{C}\right)$ & $\Delta G^{\circ}(\mathrm{kj} / \mathrm{mol})$ & $\Delta H^{\circ}(\mathrm{kj} / \mathrm{mol})$ & $\Delta S^{\circ}(\mathrm{j} / \mathrm{mol} \mathrm{K})$ & $R^{2}$ \\
\hline $\mathrm{Pb}(\mathrm{II})$ & 20 & -20.9841 & 25.2563 & 157.891 & 0.9952 \\
& 30 & -22.6617 & & & \\
& 40 & -24.1383 & & & \\
$\mathrm{Cu}(\mathrm{II})$ & 20 & -18.7148 & 8.5310 & 93.1420 & 0.8859 \\
& 30 & -19.8179 & & & \\
& 40 & -20.5702 & & & \\
$\mathrm{Cr}(\mathrm{VI})$ & 20 & -11.0190 & 16.2264 & 93.2248 & 0.9156 \\
& 30 & -12.2269 & & & \\
& 40 & -12.8711 & & & \\
\hline
\end{tabular}

adsorption are positive, indicating endothermic processes which were also predicted before (Sharma et al. 2019). The endothermic nature of adsorption can be attributed to increase in the mobility of the heavy metal ions and increase in the rate of diffusion of the adsorbate molecules across the external boundary layer and in the internal pores of the adsorbent particle, because of the decrease in the viscosity of the solution. Otherwise, negative $\Delta G^{\circ}$ values show the feasibility and spontaneity of the adsorption process, and the positive $\Delta S^{\circ}$ values show that affinity of metal ions is sufficient to stick on the carbon surface and randomness at the interface of $\mathrm{AC}$-metal solution interphase increased during this process (Li et al. 2016; Enniya et al. 2018).

\section{Conclusions}

This paper suggests an environmentally friendly process for utilization of an agro-waste for AC production and removal of $\mathrm{Pb}(\mathrm{II}), \mathrm{Cu}(\mathrm{II})$, and $\mathrm{Cr}(\mathrm{VI})$ from aqueous solutions onto produced carbon. The following conclusions can be drawn based on the study:

- The surface area of the chemically prepared AC from chickpea husk was relatively high, especially for which was prepared by $\mathrm{KOH}$ with an impregnation ratio of $50 \%$ $\left(2082 \mathrm{~m}^{2} / \mathrm{g}\right)$.

- The adsorption of $\mathrm{Pb}(\mathrm{II}), \mathrm{Cu}(\mathrm{II})$, and $\mathrm{Cr}(\mathrm{VI})$ on chemically produced $\mathrm{AC}$ by $\mathrm{KOH}$ is found to be effected by $\mathrm{pH}$, adsorbent dose, initial metal concentration, temperature, and contact time

- $\mathrm{Pb}$ (II) is preferentially adsorbed on the surface of the $\mathrm{KOH}$ AC than $\mathrm{Cu}(\mathrm{II})$ and $\mathrm{Cr}(\mathrm{VI})$.

- Comparison of the equilibrium models shows that Freundlich model fits with the experimental data better than other isotherms, which indicates multilayer adsorption.

- Adsorption kinetics of $\mathrm{Pb}(\mathrm{II}), \mathrm{Cu}(\mathrm{II})$, and $\mathrm{Cr}(\mathrm{VI})$ ions was explained with the pseudo-second-order model. 
- The thermodynamic calculations indicated endothermic and spontaneous nature of the metal ions adsorption onto produced AC.

As a result, this study represented that agricultural wastes can be converted to effective and low-cost adsorbent materials in an eco-friendly manner since chickpea-husk-derived AC showed a satisfactory adsorption performance due to its high surface area and high adsorption capacity.

Open Access This article is distributed under the terms of the Creative Commons Attribution 4.0 International License (http://creativeco mmons.org/licenses/by/4.0/), which permits unrestricted use, distribution, and reproduction in any medium, provided you give appropriate credit to the original author(s) and the source, provide a link to the Creative Commons license, and indicate if changes were made.

\section{References}

Abbas M, Kaddour S, Trari M (2014) Kinetic and equilibrium studies of cobalt adsorption on apricot stone activated carbon. J Ind Eng Chem 20(3):745-751

Abdel-Ghani NT, El-Chaghaby GA, ElGammal MH, Rawash ESA (2016) Optimizing the preparation conditions of activated carbons from olive cake using $\mathrm{KOH}$ activation. New Carbon Mater 31(5):492-500

Abdulrazak S, Hussaini K, Sani HM (2017) Evaluation of removal efficiency of heavy metals by low-cost activated carbon prepared from African palm fruit. Appl Water Sci 7(6):3151-3155

Agarwal M, Singh K (2017) Heavy metal removal from wastewater using various adsorbents: a review. J Water Reuse Desalin 7(4):387-419

Ahmady-Asbchin S, Andres Y, Gerente C, Cloirec PL (2009) Natural seaweed waste as sorbent for heavy metal removal from solution. Environ Technol 30(7):755-762

Ahmed MJ, Theydan SK (2012) Adsorption of cephalexin onto activated carbons from Albizia lebbeck seed pods by microwaveinduced $\mathrm{KOH}$ and $\mathrm{K}_{2} \mathrm{CO}_{3}$ activations. Chem Eng J 211:200-207

Akpomie KG, Dawodu FA, Eze SI, Asegbeloyin JN, Ani JU (2018) Heavy metal remediation from automobile effluent by thermally treated montmorillonite-rice husk composite. Trans R Soc S Afr 73(3): $1-10$

Al-Ghamdi A, Altaher H, Omar W (2013) Application of date palm trunk fibers as adsorbents for removal of $\mathrm{Cd}^{+2}$ ions from aqueous solutions. J Water Reuse Desalin 3(1):47-54

Alhashimi HA, Aktas CB (2017) Life cycle environmental and economic performance of biochar compared with activated carbon: a meta-analysis. Resour Conserv Recycl 118:13-26

Andas J, Satar NAA (2018) Synthesis and characterization of tamarind seed activated carbon using different types of activating agents: a comparison study. Mater Today Proc 5(9):17611-17617

Bestawy EE, Helmy S, Hussien H, Fahmy M, Amer R (2013) Bioremediation of heavy metal-contaminated effluent using optimized activated sludge bacteria. Appl Water Sci 3(1):181-192

Cechinel MAP, de Souza AAU (2014) Study of lead (II) adsorption onto activated carbon originating from cow bone. J Clean Prod 65:342-349

Chen JP, Wu S, Chong KH (2003) Surface modification of a granular activated carbon by citric acid for enhancement of copper adsorption. Carbon 41(10):1979-1986

Chen Y, Huang B, Huang M, Cai B (2011) On the preparation and characterization of activated carbon from mangosteen shell. J Taiwan Inst Chem Eng 42(5):837-842
Chen R, Li L, Liu Z, Lu M, Wang C, Li H, Ma W, Wang S (2017) Preparation and characterization of activated carbons from tobacco stem by chemical activation. J Air Waste Manag Assoc 67(6):713-724

Deng H, Li G, Yang H, Tang J, Tang J (2010) Preparation of activated carbons from cotton stalk by microwave assisted $\mathrm{KOH}$ and $\mathrm{K}_{2} \mathrm{CO}_{3}$ activation. Chem Eng J 163(3):373-381

Dubinin MM, Radushkevich LV (1947) Equation of the characteristic curve of activated charcoal. Proc Acad Sci USSR Phys Chem Sect 55:331

Elovich SY, Larinov OG (1962) Theory of adsorption from solutions of non-electrolytes on solid (I) equation adsorption from solutions and the analysis of its simplest form, (II) verification of the equation of adsorption isotherm from solutions. Izv Akad Nauk SSSR Otd Khim Nauk 2(2):209-216

Enniya I, Rghioui L, Jourani A (2018) Adsorption of hexavalent chromium in aqueous solution on activated carbon prepared from apple peels. Sustain Chem Pharm 7:9-16

Farnane M, Tounsadi H, Machrouhi A, Elhalil A, Mahjoubi FZ, Sadiq M, Abdennouri S, Qourzal S, Barka N (2017) Dye removal from aqueous solution by raw maize corncob and $\mathrm{H}_{3} \mathrm{PO}_{4}$ activated maize corncob. J Water Reuse Desal, In press

Foo KY, Hameed BH (2011) Utilization of rice husks as a feedstock for preparation of activated carbon by microwave induced $\mathrm{KOH}$ and $\mathrm{K}_{2} \mathrm{CO}_{3}$ activation. Biores Technol 102(20):9814-9817

Foo KY, Hameed BH (2012) Mesoporous activated carbon from wood sawdust by $\mathrm{K}_{2} \mathrm{CO}_{3}$ activation using microwave heating. Biores Technol 111:425-432

Food and Agriculture Organization of the United Nations (FAO) Website, http://www.fao.org/corp/statistics/en/. Last Accessed, June 2017

Freundlich HMF (1906) Über die adsorption in lösungen. Z Phys Chem 57:385-470

González JF, Román S, Encinar JM, Martínez G (2009) Pyrolysis of various biomass residues and char utilization for the production of activated carbons. J Anal Appl Pyrol 85(1):134-141

Gurten II, Ozmak M, Yagmur E, Aktas Z (2012) Preparation and characterisation of activated carbon from waste tea using $\mathrm{K}_{2} \mathrm{CO}_{3}$. Biomass Bioenergy 37:73-81

Hameed KS, Muthirulan P, Sundaram MM (2017) Adsorption of chromotrope dye onto activated carbons obtained from the seeds of various plants: equilibrium and kinetics studies. Arab J Chem 10:S2225-S2233

Han T, Zhang X, Fu X, Liu J (2017) Facile synthesis of chitosan nanoparticle-modified $\mathrm{MnO}_{2}$ nanoflakes for ultrafast adsorption of $\mathrm{Pb}(\mathrm{II})$ from aqueous solution. Water Sci Technol Water Supply 17(1):32-38

Hayashi JI, Horikawa T, Muroyama K, Gomes VG (2002) Activated carbon from chickpea husk by chemical activation with $\mathrm{K}_{2} \mathrm{CO}_{3}$ : preparation and characterization. Microporous Mesoporous Mater 55(1):63-68

Hirunpraditkoon S, Tunthong N, Ruangchai A, Nuithitikul K (2011) Adsorption capacities of activated carbons prepared from bamboo by $\mathrm{KOH}$ activation. World Acad Sci Eng Technol 78:711-715

Ho YS, McKay G (1999) Pseudo-second order model for sorption processes. Process Biochem 34(5):451-465

Hossain MA, Ngo HH, Guo W, Zhang J, Liang S (2014) A laboratory study using maple leaves as a biosorbent for lead removal from aqueous solutions. Water Qual Res J Can 49(3):195-209

Hussain J, Husain I, Arif M, Gupta N (2017a) Studies on heavy metal contamination in Godavari river basin. Appl Water Sci 7:4539-4548

Hussain A, Maitra J, Khan KA (2017b) Development of biochar and chitosan blend for heavy metals uptake from synthetic and industrial wastewater. Appl Water Sci 7:4525-4537

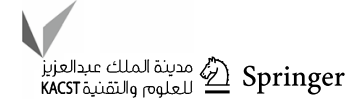


Kataria N, Garg VK (2018) Optimization of Pb(II) and Cd (II) adsorption onto $\mathrm{ZnO}$ nanoflowers using central composite design: isotherms and kinetics modelling. J Mol Liq 271:228-239

Kaur R, Singh J, Khare R, Cameotra SS, Ali A (2013) Batch sorption dynamics, kinetics and equilibrium studies of $\mathrm{Cr}(\mathrm{VI}), \mathrm{Ni}$ (II) and $\mathrm{Cu}$ (II) from aqueous phase using agricultural residues. Appl Water Sci 3(1):207-218

Kilic M, Apaydin-Varol E, Pütün AE (2011) Adsorptive removal of phenol from aqueous solutions on activated carbon prepared from tobacco residues: equilibrium, kinetics and thermodynamics. J Hazard Mater 189(1-2):397-403

Kılıç M, Apaydın-Varol E, Pütün AE (2012) Preparation and surface characterization of activated carbons from Euphorbia rigida by chemical activation with $\mathrm{ZnCl}_{2}, \mathrm{~K}_{2} \mathrm{CO}_{3}, \mathrm{NaOH}$ and $\mathrm{H}_{3} \mathrm{PO}_{4}$. Appl Surf Sci 261:247-254

Kwiatkowski M, Broniek E (2017) An analysis of the porous structure of activated carbons obtained from hazelnut shells by various physical and chemical methods of activation. Colloids Surf A 529:443-453

Lagergren S (1898) Zurtheorie der sogenannten adsorption gelosterstoffe. Kungliga Svenska Vetenskapsakademiens, Handlingar 24:1-39

Langmuir I (1917) The constitution and fundamental properties of solids and liquids. J Franklin Inst 183(1):102-105

Langmuir I (1918) The adsorption of gases on plane surfaces of glass, mica and platinum. J Am Chem Soc 40:1361-1403

Li L, Liu F, Duan H, Wang X, Li J, Wang Y, Luo C (2016) The preparation of novel adsorbent materials with efficient adsorption performance for both chromium and methylene blue. Colloids Surf B 141:253-259

Li S, Han K, Li J, Li M, Lu C (2017) Preparation and characterization of super activated carbon produced from gulfweed by $\mathrm{KOH}$ activation. Microporous Mesoporous Mater 243:291-300

Malik DS, Jain CK, Yadav AK (2017) Removal of heavy metals from emerging cellulosic low-cost adsorbents: a review. Appl Water Sci $7(5): 2113-2136$

Mashkoor F, Nasar A (2019) Preparation, characterization and adsorption studies of the chemically modified Luffa aegyptica peel as a potential adsorbent for the removal of malachite green from aqueous solution. J Mol Liq 274:315-327

Muniandy L, Adam F, Mohamed AR, Ng EP (2014) The synthesis and characterization of high purity mixed microporous/mesoporous activated carbon from rice husk using chemical activation with $\mathrm{NaOH}$ and KOH. Microporous Mesoporous Mater 197:316-323

Neimark AV, Lin Y, Ravikovitch PI, Thommes M (2009) Quenched solid density functional theory and pore size analysis of micromesoporous carbons. Carbon 47(7):1617-1628

Okman I, Karagöz S, Tay T, Erdem M (2014) Activated carbons from grape seeds by chemical activation with potassium carbonate and potassium hydroxide. Appl Surf Sci 293:138-142

Omar WS (2015) Treatment of wastewaters contaminated with zinc ions using natural zeolite as adsorbent in a fixed bed column. J Water Reuse Desalin 5(4):542-549

Pakade VE, Nchoe OB, Hlungwane L, Tavengwa NT (2017) Sequestration of hexavalent chromium from aqueous solutions by activated carbon derived from Macadamia nutshells. Water Sci Technol 75(1):196-206

Rakić V, Rac V, Krmar M, Otman O, Auroux A (2015) The adsorption of pharmaceutically active compounds from aqueous solutions onto activated carbons. J Hazard Mater 282:141-149

Ramana DKV, Jamuna K, Satyanarayana B, Venkateswarlu B, Rao MM, Seshaiah K (2010) Removal of heavy metals from aqueous solutions using activated carbon prepared from Cicer arietinum. Toxicol Environ Chem 92(8):1447-1460

Ramesh ST, Rameshbabu N, Gandhimathi R, Nidheesh PV, Kumar MS (2012) Kinetics and equilibrium studies for the removal of heavy metals in both single and binary systems using hydroxyapatite. Appl Water Sci 2(3):187-197
Rana P, Mohan N, Rajagopal C (2004) Electrochemical removal of chromium from wastewater by using carbon aerogel electrodes. Water Res 38(12):2811-2820

Reddy KSK, Kannan P, Al Shoaibi A, Srinivasakannan C (2014) KOHbased porous carbon from date palm seed: preparation, characterization, and application to phenol adsorption. Water Sci Technol 70(10):1633-1640

Rio S, Martin P (2012) Removal of metal ions from aqueous solution by adsorption onto low-cost biosorbent. Environ Technol 33(19):2211-2215

Sdiri A, Higashi T (2013) Simultaneous removal of heavy metals from aqueous solution by natural limestones. Appl Water Sci 3(1):29-39

Semerjian L (2018) Removal of heavy metals $(\mathrm{Cu}, \mathrm{Pb})$ from aqueous solutions using pine (Pinus halepensis) sawdust: equilibrium, kinetic, and thermodynamic studies. Environ Technol Innov 12:91-103

Sharma M, Singh J, Hazra S, Basu S (2019) Adsorption of heavy metal ions by mesoporous $\mathrm{ZnO}$ and $\mathrm{TiO} 2 @ \mathrm{ZnO}$ monoliths: adsorption and kinetic studies. Microchem J 145:105-112

Shu Y, Li K, Song J, Li B, Tang C (2016) Single and competitive adsorption of $\mathrm{Cd}$ (II) and $\mathrm{Pb}$ (II) from aqueous solution by activated carbon prepared with Salix matsudana Kiodz. Water Sci Technol 74(12):2751-2761

Taamneh Y, Sharadqah S (2016) The removal of heavy metals from aqueous solution using natural Jordanian zeolite. Appl Water Sci 7(4):2021-2028

Tan IAW, Chan JC, Hameed BH, Lim LLP (2016) Adsorption behavior of cadmium ions onto phosphoric acid-impregnated microwave-induced mesoporous activated carbon. J Water Process Eng 14:60-70

Tang XW, Li ZZ, Chen YM, Wang Y (2008) Removal of Cu (II) from aqueous solution by adsorption on Chinese quaternary loess: kinetics and equilibrium studies. J Environ Sci Health A 43(7):779-791

Temkin MJ, Phyzev V (1940a) Recent modifications to Langmuir isotherms. Acta Physiochim USSR 12:217-222

Temkin MJ, Phyzev V (1940b) Kinetic of ammonia synthesis on promoted iron catalysts. Acta Physiochim USSR 12:237-356

Thitame PV, Shukla SR (2016) Porosity development of activated carbons prepared from wild almond shells and coir pith using phosphoric acid. Chem Eng Commun 203(6):791-800

Tongpoothorn W, Sriuttha M, Homchan P, Chanthai S, Ruangviriyachai C (2011) Preparation of activated carbon derived from Jatropha curcas fruit shell by simple thermo-chemical activation and characterization of their physico-chemical properties. Chem Eng Res Des 89(3):335-340

Valizadeh S, Younesi H, Bahramifar N (2016) Highly mesoporous $\mathrm{K}_{2} \mathrm{CO}_{3}$ and $\mathrm{KOH} /$ activated carbon for SDBS removal from water samples: batch and fixed-bed column adsorption process. Environ Nanotechnol Monit Manag 6:1-13

Vassileva P, Detcheva A, Uzunov I, Uzunova S (2013) Removal of metal ions from aqueous solutions using pyrolyzed rice husks: adsorption kinetics and equilibria. Chem Eng Commun 200(12):1578-1599

Wang J, Zhao Y, Zhang P, Yang L, Xi G (2018) Adsorption characteristics of a novel ceramsite for heavy metal removal from stormwater runoff. Chin J Chem Eng 26(1):96-103

Weber WJ, Morris JC (1963) Kinetics of adsorption on carbon from solution. J Sanit Eng Div 89(2):31-60

Yang R, Liu G, Li M, Zhang J, Hao X (2012) Preparation and $\mathrm{N}_{2}, \mathrm{CO}_{2}$ and $\mathrm{H}_{2}$ adsorption of super activated carbon derived from biomass source hemp (Cannabis sativa L.) stem. Microporous Mesoporous Mater 158:108-116

Zhang X, Zhu Z (2015) Lead sorption performance on active silica derived from fly ash. Water Sci Technol 71(5):661-666

Publisher's Note Springer Nature remains neutral with regard to jurisdictional claims in published maps and institutional affiliations. 